\title{
DOE/ER/62476-1
}

\section{FINAL REPORT}

\author{
Project Title: Horizontal gene transfer as adaptive response to heavy metGFPatent Clearance Granted \\ communities \\ Principal Investigator: Barth F. Smets, Ph. D. \\ Mark D. Dirscak \\ (630: $25 \%-2 ; 345$ \\ E-miall nark dworscak@ch.doe.gov \\ Period Covered by Report: Oct 15, 1997 - Oct 15, 2000 \\ Office o: inietlicitual Property Law \\ DOE Chicago Operations Office
}

Recipient Organization: University of Connecticut, 438 Whitney Road Ext., Storrs CT

DOE Award Number: DE-FG02-97ER62476

Collaborators: Catalina Arango P.,Ph.D., Jayne B. Morrow, Olga Zelennikova, Stefanie Vandaele, Matthew Panciera, Michelle Ng, Erzsebet Pocsi, Doug Marcotte, Don Stadolnik

\section{Results}

The hypothesis of our research project was that microbial communities respond to sub-toxic heavy metal stress by increased horizontal gene transfer and rearrangement. We postulated that such response leads to useful genetic rearrangements and recombinations that improve the community's ability to resist or cope with the applied heavy metal stress. Our thrust was, therefore, to directly examine gene transfer in soil microcosms subject to different levels of heavy metal stress and examine this for soils that were either pristine or had historic heavy metal contamination.

In our microcosm experiments we mimicked the conditions of a semi-continuous oligotrophic carbon flux that exists in the subsurface. Samples were obtained from the saturated zone of an alluvial deposit aquifer at a site contaminated with $\mathrm{Cd}$ and $\mathrm{Zn}$ adjacent to a closed metal plating waste lagoon. The actual total and $\mathrm{NaNO}_{3}$ exchangeable metal concentrations were $79 \mathrm{microg} / \mathrm{g} \mathrm{Cd}^{2+}, 96 \mathrm{microg} / \mathrm{g} \mathrm{Ni}^{2+}, 63 \mathrm{microg} / \mathrm{g} \mathrm{Zn}^{2+}$; and $35 \mathrm{microg} / \mathrm{g} \mathrm{Cd}^{2+}, 8 \mathrm{microg} / \mathrm{g} \mathrm{Ni}^{2+}$, and $5 \mathrm{microg} / \mathrm{g} \mathrm{Zn}^{2+}$ respectively. In addition, our approach permitted facile periodic sampling of the microbial community. In brief, each microcosm consisted of subsurface soil aliquots placed in $40-\mathrm{ml}$ sample vial subject to periodic (2/week) addition and withdrawal of artificial groundwater (AGW) supplemented with a low carbon concentration (peptone at $10 \mathrm{mg} / \mathrm{L}$ ) to maintain a low carbon flux in the system. The withdrawn samples were then subject to molecular analysis and microbial enumeration. Repeated addition and withdrawal of AGW allow long-term (10 to 30+ weeks) operation of the microcosm. In most experiments, $\mathrm{Cd}$ was studied as model heavy metal stress at different concentrations $\left(C_{T, C d}=0,10,100,1000\right.$ microM $)$. All treatments were conducted in duplicate and contained controls to assess background contribution of the indigenous community to various analyses.

Several long-term microcosm experiments were completed. In a first set, the fate of Pseudomonas putida KT2440 and its plasmid TOL::Tn5npt was monitored at various degrees of Cd stress. This strain was originally proposed as the model delivery system for our work, because it contains a chromosomal copy of the $\mathrm{P}_{\mathrm{AL}-030+5}$ gef-based IPTG inducible suicide gene cassette present on a miniTns. Hence, the efficacy of suicide induction in the microcosm systems was examined. Our results indicated, however, that the $\mathrm{P}_{\mathrm{Al}-0304}-$ gef suicide miniTn 5 construct was not an effective means of selective elimination of a bacterial plasmid donor in tested soil microcosms, due to the combined effects of spontaneous loss of the mini-transposon, spontaneous mutations in the $\mathrm{P}_{\mathrm{A}-030 \mathrm{~s}}-$-gef cassette and rapid selection of escape mutants upon suicide induction. Due to the inefficacy of the suicide system for selective plasmid donor removal, several Escherichia coli strains were subsequently used for plasmid delivery in the microcosm given their presumed competitive inferiority. 


\section{DISCLAIMER}

This report was prepared as an account of work sponsored by an agency of the United States Government. Neither the United States Government not any agency thereof, nor any of their employees, makes any warranty, express or implied, or assumes any legal liability or responsibility for the accuracy, completeness, or usefulness of any information, apparatus, product, or process disclosed, or represents that its use would not infringe privately owned rights. Reference herein to any specific commercial product, process, or service by trade name, trademark, manufacturer, or otherwise does not necessarily constitute or imply its endorsement, recommendation, or favoring by the United States Government or any agency thereof. The views and opinions of authors expressed herein do not necessarily state or reflect those of the United States Government or any agency thereof. 


\section{DISCLAIMER}

Portions of this document may be illegible in electronic image products. Images are produced from the best available original document. 
Using subsurface soils historically contaminated with $\mathrm{Zn}^{2+}, \mathrm{Cd}^{2+}$, and $\mathrm{Ni}^{2+}$, we examined the fate of two RSF1010 plasmids (IncQ, tra- mob+; pMOL 187 and pMOL 222 containing the $c z c$ and ncc operons, respectively) originally introduced with $E$. coli donors in semi-continuously operated microcosms at increasing Cd concentrations. Further, we examined whether the long-term stability of the plasmid in the community was enhanced by the simultaneous co-introduction of the broad-host range plasmid RP4 (IncP $\alpha$, tra+ mob+). Hence, all treatments were examined in absence or presence of RP4. While the stability of the introduced $E$. coli strain (pMOL222 or pMOL187 result in low level heavy metal resistance in $E$. coli) was somewhat impacted by the degree of metal contamination, the strains were typically not recoverable after 4 weeks of operation. Total culturable cell counts remained in the range of $10^{5}$ to $10^{7}$ cells $/ \mathrm{ml}$ throughout the microcosm operation. Increases in the degree of heavy metal resistance were observed only at the highest $\mathrm{Cd}$ addition suggesting little effect of the applied stress on the community phenotype below $1 \mathrm{mM} \mathrm{Cd}$. No clear phenotypic evidence of pMOL 187 or pMOL 222 transfer could not be obtained: increases in Cd or Ni resistance were associated with applied $\mathrm{Cd}$ dose rather than the addition of the plasmids. Thus, ID-PCR was employed to enumerate the abundance of $c z c$ harbored on pMOL187 and ncc harbored on pMOL222. We obtained an ID-PCR detection limit of $1.210^{3}$ and $1.610^{3}$ copies in a background of $10^{8}$ cells for $c z c$ and $n c c$, respectively. Further, introduced $E$. coli strains were detected employing ID-PCR targeting $r r s A 3$ (E. coli MG1655) that permitted specific enumeration of enteric bacteria. RP4 was detected employing IncPrep specific primers which target the replication function trafA1. Simultaneous RP4 introduction consistently enhanced pMOL187 and pMOL222 stability in the microbial community, suggesting that the plasmids were mobilized by the introduced RP4 plasmid. Transiently ( 2 to 3 weeks after introduction) high titers of $10^{5}$ and $10^{3}$ templates per ml were measured for pMOL187 and pMOL222, respectively. Further, $c z c$ was still observed in microcosms after 32 weeks $\left(10^{2}\right.$ per $\left.\mathrm{ml}\right)$ but only if RP4 was cointroduced, although ID-PCR with IncPrep specific primers for RP4 did not reveal continued persistence of RP4 and also introduced $E$. coli strains were confirmed absent at this point. The effect of increased Cd concentrations on $c z c$ persistence was marginal. Exogenous isolation using Ralstonia metallodurans as capturing strain was performed to reisolate the IncQ plasmid from the indigenous microbial community. The plasmid was only reisolated from the microcosms containing solely E. coli (pMOL222), for which a transfer frequency of $2 \times 10^{-8}$ (cells $/ \mathrm{ml}$ transconjugants $/$ cells $/ \mathrm{ml}$ recipients) was obtained, suggesting a low mobilization potential of the soil community. Transconjugants from the indigenous community harboring pMOL222 were identified by enumeration on increasing Ni concentration and detection of $n c c$ by filterhybridization.

Our results have clearly indicated that plasmid transfer in oligotrophic and metal-impacted subsurface microbial communities can occur at detectable frequencies. Rather than examine transfer to co-introduced recipient strains, we have followed transfer into the indigenous community employing molecular enumeration of relevant genes The extent of plasmid transfer may be limited by the mobilization potential of the indigenous community. This is remarkable, since our phenotypic community assessement did not reveal a clear benefit of the introduced plasmid. Within the range examined, metal stress did not seem to affect plasmid incidence in the community.

Several questions are raised by our research findings: What is the normal plasmid pool in the studied microbial communities, and how reflective are our model plasmids to study the dynamics of indigenous plasmids? What is the host range of our model plasmids, and what is the mobilization potential of such communities for indigenous plasmids? Is there a difference between long-term stressed and short-term perturbed microbial communities in terms of horizontal gene transfer? What molecular rearrangements occur in concordance with horizontal gene transfer, and do any of these results in adaptive traits endowed to the community? What is the physiological basis of the effect of various chemical stressors on bacterial activity and horizontal gene transfer? Answering these questions, in appropriate model systems and environments, will allow us to better ascertain the significance of horizontal gene transfer as an adaptive response in microbial communities subject to anthropogenic influences. 


\section{Products Delivered}

Conference presentations made during the project duration that were, wholly or in part, funded by this research program:

1. Arango, C. P., J. B. Morrow, B. Torres, E. M. Pocsi, and B. F. Smets 2001. Plasmid transfer evaluation in soil microbial communities under environmental stress. $6^{\text {th }}$ International In Situ and OnSite Bioremediation Symposium. June 4-7, San Diego, CA.

2. Morrow, J. B., and B. F. Smets 2000 . Abundance of heavy metal resistance plasmids in subsurface microbial communities under varying degrees of cadmium stress. Division of Environmental Chemistry (Preprints of Extended Abstracts p. 380-382) ACS $220^{d}$ National Meeting, Aug. 20-24, Washington, D.C.

3. Zelennikova, O., J. S. Billmayer, M. A. Panciera, and B. F. Smets 1999. Horizontal gene transfer in subsurface microbial community under heavy metal stress. $4^{\text {th }}$ International Symposium of Subsurface Microbiology, ASM, Aug. 22-27, Vail CO.

4. Zelennikova, O., M. A. Panciera, and B. F. Smets 2001 . Subsurface microbial community changes in response to carbon source addition to stimulate haloreduction. ACS $221^{\text {st }}$ National Meeting, April 1-5, San Diego, CA.

5. Panciera, M. A., O. Zelennikova, B. F. Smets, and G. M. Dobbs 2001. Differential stimulation of haloreduction by carbon addition to subsurface addition to subsurface soils. $6^{\text {th }}$ International In Situ and On-Site Bioremediation Symposium. June 4-7, San Diego, CA.

6. Panciera, M. A., O. Zelennikova, and B. F. Smets 2000. Reductive transformation of chlorinated ethenes: Microcosm studies to elucidate biological processes in the subsurface, p. 182-191. 32 $\mathrm{did}$ Atlantic Industrial and Hazardous Waste Conference, June 26-28, Troy, NY. Technomic, Lancaster PA.

\section{Notes}

Several manuscripts are in advanced preparation and will be submitted with acknowledgement of funding under this research program. Preprints will be submitted to the program manager once available.

1. Morrow, J. B., C. Arango, and B. F. Smets. 2001. Maintenance of introduced non-conjugal Inc- $Q$ plasmids in subsurface microbial communities is limited by the indigenous mobilization potential.

2. Arango, C., S. M. Vandaele, O. Zelennikova, and B. F. Smets. 2001. Conjugal transfer of a TOL plasmid under metal and solvent- stressed conditions.

3. Arango, C., B. Torres, and B. F. Smets. 2001. Evalution of a gef-based IPTG inducible suicide gene system for use in experimental microcosms. 